\title{
Mobile phone use pattern and addiction in relation to depression and anxiety
}

Dalia El-Sayed Desouky ${ }^{1,2}$ and Hany Abu-Zaid ${ }^{1}$

${ }^{1}$ Department of Family and Community Medicine, College of Medicine, Taif University, Taif, Saudi Arabia (Correspondence to: D. El-Sayed Desouky: daliadesouky1234@gmail.com). ${ }^{2}$ Department of Public Health and Community Medicine, Faculty of Medicine, Menoufia University, Menoufia, Egypt.

\begin{abstract}
Background: University students with heavy smartphone use are vulnerable to smartphone addiction that could be related to depression and trait anxiety.

Aims: To assess gender differences in patterns of smartphone use and addiction in relation to depression and trait anxiety among Saudi university students.

Methods: This was a cross-sectional study of 1513 students of Taif University, Saudi Arabia. A self-reported questionnaire was used to collect demographic data and data on pattern of smartphone use. The Problematic Use of Mobile Phones (PUMP) scale was used to determine smartphone addiction. The Arabic validated version of the Taylor Manifest Anxiety Scale and Beck Depression Inventory were used to assess trait anxiety and depression, respectively.

Results: A female predominance was found for: prevalence of depression and trait anxiety, PUMP scores, duration of daily mobile use and number of daily calls. A significant positive correlation was found between PUMP score and depression and trait anxiety scores, duration of owning a smartphone, and average duration of each daily call. The PUMP scores were significantly higher in 6th year students, those from the theoretical college, single students, and students who used a smartphone for $>4$ hours/day.

Conclusions: Smartphone addiction is a major problem among Saudi university students, and it is associated with depression and trait anxiety. Future studies should aim to establish the best interventions to protect university students from the negative effects of smartphones.

Keywords: addiction, anxiety, depression, smartphone, university students.

Citation: El-Sayed Desouky D; Abu-Zaid H. Mobile phone use pattern and addiction in relation to depression and anxiety. East Mediterr Health J. 2020;26(6):692-699. https://doi.org/10.26719/emhj.20.043

Received: 04/03/18; accepted:17/02/19

Copyright (c) World Health Organization (WHO) 2020. Open Access. Some rights reserved. This work is available under the CC BY-NC-SA 3.0 IGO license (https://creativecommons.org/licenses/by-nc-sa/3.o/igo).
\end{abstract}

\section{Introduction}

Smartphones, as well as being telephones, act as internet browsers, social networking facilitators, cameras and multimedia players (1). Overuse of smartphones is associated with adverse effects on daily lives (2), leading to sleep, education, relationship and work problems; stress, loneliness, aggression, hostility and reduced quality of life (3); and adverse effects on physical $(4)$ and mental $(5,6)$ health.

Smartphones enable university students to know the latest advances in communications technology, and to make rapid contact with their friends and families (6). College students with heavy smartphone use are vulnerable to smartphone addiction (7-10), which is defined as "the excessive uncontrolled use of the smartphone despite the awareness of the consequences, with the presence of withdrawal symptoms in any attempt to control" (11). A systematic review has found that severity of depression and anxiety is directly related to smartphone addiction (5), and the same finding has been demonstrated in previous studies of university students $(6,9)$.

According to a study done by United Nations Conference on Trade and Development (UNCTAD), Saudi
Arabia ranked first in the world for the highest proportion of mobile phone users (12), with a smartphone distribution rate of $86.1 \%$ in 2015 (10). A few recent Saudi studies have addressed smartphone addiction and its psychological adverse effects. One study was done on students of King Saud University, and found a prevalence of smartphone addiction of $48 \%$, with a significant gender differences in the degree of addiction (13). Another study was done in the same university and assessed the adverse physical effects of smartphone addiction on academic performance (14).

Only 2 studies have investigated the relationship between smartphone addiction and depression; 1 on medical students (10), and the other on female high school students (15).

Previous researchers have found gender differences in smartphone addiction $(6,16)$. No Saudi study has assessed gender difference, which is vital in planning targeted prevention and intervention strategies to deal with this problem. The aim of the present study was to assess the gender differences in pattern of smartphone use and addiction in relation to depression and trait anxiety among Saudi university students. 


\section{Methods}

\section{Study design}

This was a cross-sectional study of students of Taif University, Taif, Saudi Arabia from November 2017 to March 2018.

\section{Sampling methodology}

Multistage sampling was carried out, and the university community of Taif University was the sampling frame. From the 4 health colleges of Taif University, 1 was chosen by simple random sampling, and the same was done to choose 1 college out of the 7 theoretical colleges, where the male and female sections of each college were included. There were 2138 students registered in both female and male sections of the 2 colleges in the academic year 2017-2018. The response rate was $74.5 \%$ and the total number of participants was 1594 students.

\section{Ethical considerations}

The study was reviewed and approved by the Research Ethics Committee of Taif University and from the deanships of the chosen colleges. Verbal consent was obtained from the participating students.

\section{Study instrument}

A predesigned questionnaire was used with the first few questions on the demographic characteristics, college type and educational grade.

In the first section, those who replied yes to ownership of a smartphone were qualified to answer the subsequent sections. Of the 1594 participants, 1570 (98.49\%) had a smartphone. Of the 1570 questionnaires, 57 incomplete questionnaires were excluded, leaving 871 valid questionnaires from students of the health college and 642 from the theoretical college.

The second section included questions on patterns of smartphone use.

The third section was the Arabic validated version of the Problematic Use of Mobile Phones (PUMP) scale that was used to assess smartphone addiction. The Arabic version of this scale was validated in a previous Saudi study (17), and had excellent internal consistency and convergent validity $(18,19)$. The scale includes 20 questions based on the Diagnostic and Statistical Manual of Mental Disorders (DSM-5) criteria for substance use disorder $(17,18)$, and every question was answered on a Likert scale of $1-5$. The total score ranged from 20 to 100 , with higher scores indicating more usage and more problematic use.

The fourth section assessed trait anxiety levels using the Arabic validated version of the Taylor Manifest Anxiety Scale that consists of 50 questions. Students' trait anxiety level was assessed as follows: normal (score of $0-16)$, mild (17-20), moderate (21-26), severe (27-29), and very severe (30-50) (19).

In the fifth section, depression level was assessed using the Arabic version of the Beck Depression Inventory that includes 21 items. Every item was scored from o to 3 according to its severity, and the total score ranged from o to 63. The students were assessed as normal if they had a score $<26$. Depression level was assessed as follows: mild (26-38), moderate (39-55) and severe (56-63) (20).

\section{Statistical analysis}

Data were coded, tabulated and analysed using SPSS version 20 (IBM, Armonk, NY, USA). Qualitative data were expressed as numbers and percentages, and the $\chi^{2}$ test was applied to test the relationship between variables. Quantitative data were expressed as mean (standard deviation), and for nonparametric variables, as median (interquartile range). Mann-Whitney and Kruskal-Wallis tests were applied for comparison between nonparametric variables. Correlation analysis using the Spearman's test was done, and $P<0.05$ was considered statistically significant. As there was no documented cutoff point for PUMP score, we considered the median of our studied group score as a cutoff point. So, the studied group was divided into positive smartphone addiction group (score $\geq 59$ ) and negative smartphone addiction group (score < 59). Binary logistic regression analysis was performed, which analyses independent predictors with odds ratios for a binary outcome (here, smartphone addiction).

\section{Results}

The mean age of the participants was 20.58 (1.71) years. Of them, $825(54.5 \%)$ were female and 688 (45.5\%) were male, $57.6 \%$ were from health colleges, and $10.1 \%$ were married (Table 1). Depression and trait anxiety were found in $32.7 \%$ and $58.7 \%$ of students, respectively (Table 2 ).

There were gender differences (in favour of females) for: students' grades, college type, marital status, average duration of daily mobile use, duration of each daily call and number of daily calls (Table 1).

Compared to male students, female students had a significantly higher prevalence of depression $(34.9 \%$ vs $29.9 \%$ ) and trait anxiety (69.2\% vs $46.1 \%$ ) respectively (Table 2). The same gender difference was found in relation to depression and trait anxiety scores [median IQR: (18-24 vs 14-22) and (20-9 vs 13-14), respectively]. Female students showed a significantly higher median PUMP value compared to male students (median IQR: 60-27 vs 55-31, respectively).

There were significant positive correlations between PUMP score and depression score $(r=0.534, P<0.001)$, trait anxiety score $(r=0.225, P<0.001)$, duration of owning a smartphone $(\mathrm{r}=0.077, P=0.003)$, and average duration of each daily call $(\mathrm{r}=0.189, \mathrm{P}<0.001)$ respectively.

Median IQR of PUMP score was significantly higher among 6th year students $(63-30)$ compared to other grades $(P<0.001)$, and among students from theoretical colleges compared to health colleges $(63-33$ vs $53-26)(P$ $<0.001$ ) (Table 3). Single students showed a significantly higher PUMP score compared to married students (60-30 vs 52-24) $(P=0.008)$. The PUMP scores were significantly higher among students who reported average daily 
Table 1 Gender difference in characteristics and patterns of smartphone phone use

\begin{tabular}{|c|c|c|c|c|}
\hline Parameter & $\begin{array}{c}\text { Male } \\
\text { No. }(\%)\end{array}$ & $\begin{array}{l}\text { Female } \\
\text { No. (\%) }\end{array}$ & Test & $\mathbf{P}$ \\
\hline \multicolumn{5}{|l|}{ Grade } \\
\hline 1st & $155(22.5)$ & $115(13.9)$ & \multirow{6}{*}{$\begin{array}{c}\chi^{2} \\
49.94\end{array}$} & \multirow{6}{*}{$<0.001^{*}$} \\
\hline 2nd & $142(20.6)$ & $139(16.8)$ & & \\
\hline $3 \mathrm{rd}$ & $119(17.3)$ & $119(14.4)$ & & \\
\hline 4th & $110(16)$ & $138(16.7)$ & & \\
\hline 5th & $95(13.8)$ & $151(18.3)$ & & \\
\hline 6th & $67(9.7)$ & $163(19.8)$ & & \\
\hline \multicolumn{5}{|l|}{ College type } \\
\hline Health & $378(54.9)$ & $493(59.8)$ & $\chi^{2}$ & \multirow{2}{*}{0.059} \\
\hline Theoretical & $310(45.1)$ & $332(40.2)$ & 3.56 & \\
\hline \multicolumn{5}{|l|}{ Marital status } \\
\hline Married & $55(8)$ & $98(11.9)$ & \multirow{2}{*}{$\begin{array}{c}\chi^{2} \\
6.22\end{array}$} & \multirow{2}{*}{0.013} \\
\hline Unmarried & $633(92)$ & $727(88.1)$ & & \\
\hline \multicolumn{5}{|c|}{ Family monthly income (SAR) } \\
\hline$<10000$ & $217(31.5)$ & $240(29.1)$ & \multirow{3}{*}{$\begin{array}{l}\chi^{2} \\
1.1\end{array}$} & \multirow{3}{*}{0.577} \\
\hline $10000-20000$ & $318(46.2)$ & $398(48.2)$ & & \\
\hline$>20000$ & $153(22.2)$ & $187(22.7)$ & & \\
\hline \multicolumn{5}{|c|}{ Average duration of daily mobile use } \\
\hline$<2 \mathrm{~h}$ & $343(49.9)$ & $348(42.2)$ & \multirow{3}{*}{$\begin{array}{c}\chi^{2} \\
10.37\end{array}$} & \multirow{3}{*}{0.006} \\
\hline $2-4 \mathrm{~h}$ & $158(32)$ & $198(24)$ & & \\
\hline$>4 \mathrm{~h}$ & $187(27.2)$ & $279(33.8)$ & & \\
\hline \multicolumn{5}{|c|}{ Average duration of each daily call } \\
\hline$>15 \mathrm{~min}$ & $428(62.2)$ & $400(48.5)$ & \multirow{4}{*}{$\begin{array}{c}\chi^{2} \\
29.8\end{array}$} & \multirow{4}{*}{$<0.001^{*}$} \\
\hline $16-30 \mathrm{~min}$ & $154(22.4)$ & $239(29)$ & & \\
\hline $31-60 \mathrm{~min}$ & $73(10.6)$ & $129(15.6)$ & & \\
\hline$>1 \mathrm{~h}$ & $33(4.8)$ & $57(6.9)$ & & \\
\hline \multicolumn{5}{|c|}{ Age, yr, median IQR } \\
\hline & $20-3$ & $21-3$ & $\begin{array}{c}\mathrm{U} \\
2.219\end{array}$ & 0.027 \\
\hline \multicolumn{5}{|c|}{ Duration of owning smartphone, median IQR } \\
\hline & $8-3$ & $9-2$ & $\begin{array}{c}\mathrm{U} \\
0.985\end{array}$ & 0.325 \\
\hline \multicolumn{5}{|c|}{ No. of daily calls, median IQR } \\
\hline & $2-1$ & $2-2$ & $\begin{array}{c}\mathrm{U} \\
3.12 \\
\end{array}$ & 0.002 \\
\hline
\end{tabular}

$I Q R=$ interquartile range; $S A R=$ Saudi riyal; $U=$ Mann - Whitney $U$ test.

smartphone use of $>4$ hours (median IQR 65-31.25), compared to those who used the smartphone for shorter durations $(P<0.001)$. Students suffering from depression had significantly higher PUMP scores compared to those without depression (median IQR $74-20$ vs $48-22$ ) $(P<$ 0.001 ). The same was observed for students who suffered from trait anxiety (median IQR 63-30) compared to those without trait anxiety $(51-27)(P<0.001)$.

Binary logistic regression analysis showed that being female or single, older age, or having depression or trait anxiety were independent predictors for smartphone addiction (Table 4).
Table 2 Gender difference regarding depression, trait anxiety and smartphone addiction

\begin{tabular}{|c|c|c|c|c|}
\hline Parameter & $\begin{array}{c}\text { Male } \\
\text { No. (\%) }\end{array}$ & $\begin{array}{l}\text { Female } \\
\text { No. (\%) }\end{array}$ & Test & $\mathbf{P}$ \\
\hline \multicolumn{5}{|l|}{ Depression } \\
\hline Present & $206(29.9)$ & $288(34.9)$ & $\chi^{2}$ & \multirow{2}{*}{0.04} \\
\hline Absent & $482(70.1)$ & $537(65.1)$ & 4.1 & \\
\hline \multicolumn{5}{|c|}{ Type of depression $(n=494)$} \\
\hline Mild & $108(52.4)$ & 112 (38.9) & $\chi^{2}$ & \multirow{3}{*}{0.008} \\
\hline Moderate & $91(44.2)$ & $158(54.9)$ & $\begin{array}{l}n \\
9.59\end{array}$ & \\
\hline Severe & $7(3.4)$ & $18(6.3)$ & & \\
\hline \multicolumn{5}{|c|}{ Depression scores, median IQR } \\
\hline & $14-22$ & $18-24$ & $\begin{array}{c}\mathrm{U} \\
3.33\end{array}$ & 0.001 \\
\hline \multicolumn{5}{|l|}{ Trait anxiety } \\
\hline Present & $317(46.1)$ & $571(69.2)$ & \multirow{2}{*}{$\begin{array}{c}\chi^{2} \\
82.83\end{array}$} & \multirow{2}{*}{$<0.001^{*}$} \\
\hline Absent & $371(53.9)$ & $254(30.8)$ & & \\
\hline \multicolumn{5}{|c|}{ Type of trait anxiety $(n=888)$} \\
\hline Mild & $159(50.5)$ & $242(42.4)$ & \multirow{4}{*}{$\begin{array}{c}\chi^{2} \\
10.31\end{array}$} & \multirow{4}{*}{0.016} \\
\hline Moderate & $93(29.3)$ & $157(27.5)$ & & \\
\hline Severe & $43(13.6)$ & $107(18.7)$ & & \\
\hline Very severe & $22(6.9)$ & $65(11.4)$ & & \\
\hline \multicolumn{5}{|c|}{ Trait anxiety scores, median IQR } \\
\hline & $13-14$ & $20-9$ & $\begin{array}{c}\mathrm{U} \\
12.1\end{array}$ & $<0.001^{*}$ \\
\hline \multicolumn{5}{|c|}{ PUMP scores, median IQR } \\
\hline & $55-31$ & $60-27$ & $\begin{array}{l}\mathrm{U} \text { test } \\
2.74 \\
\end{array}$ & 0.006 \\
\hline
\end{tabular}

${ }^{*}$ Highly significant difference.

$I Q R=$ interquartile range; $S A R=$ Saudi riyal; $U=$ Mann-Whitney $U$ test.

\section{Discussion}

We found a female predominance for average duration of daily mobile use, average duration of each daily call, and number of daily calls, which agreed with other national and international studies $(6,14)$. Women have been found to be more addictive to social media (14), more interested in social networking (21), and always report a higher number and length of mobile calls (6). This is because women use mobile phones more in social interaction than men do (17).

The prevalence of depression (32.7\%) and trait anxiety (58.7\%) reported in the present study was in line with that reported recently in Taif University $(22,23)$. This high prevalence was attributed to academic pressure, stressful college environment, social and cultural factors, and adverse social relationships (24).

In the present study, the mean PUMP score of the whole sample [59.51 (16.93)] agreed with the mean value observed in another Saudi study [60.8 (14.9)] (14). In that study, the mean was an indicator of higher prevalence of smartphone addiction. This is consistent with another Saudi study that revealed a high level of smartphone addiction among high school students (15). The observed mean PUMP score in the present study was comparable to that observed in a study in Pakistan on university 


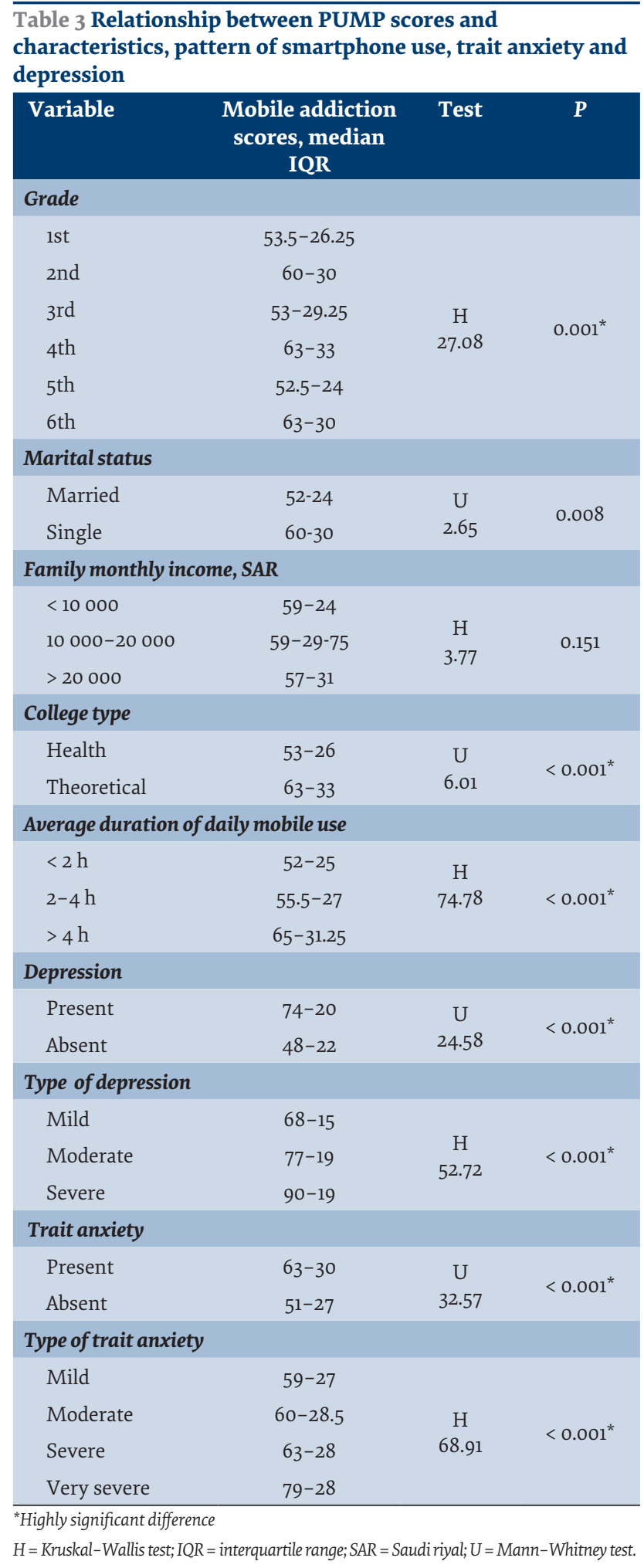

students [56.33 (15.92)] (25), and another study of Indian adolescents [59 (1.3)] (26).

The present study showed a significant gender difference according to the PUMP scores in favour of female students, as reported in other studies (6). The gender difference could have resulted from the higher trait anxiety scores among female students, which was positively correlated with PUMP scores. In addition, female students showed more moderate to severe forms of
Table 4 Binary logistic regression analysis of risk factors for smartphone addiction

\begin{tabular}{lcccc} 
Variable & \multicolumn{3}{c}{ Smartphone addiction } & $P$ \\
& $\boldsymbol{B}$ & Wald & Odds ratio & \\
\hline Sex & 0.73 & 24.23 & $\begin{array}{c}2.08 \\
(1.55-2.79)\end{array}$ & $<0.001^{*}$ \\
Age & 0.01 & 0.11 & $\begin{array}{c}1.01 \\
(0.92-1.12)\end{array}$ & 0.735 \\
Marital status & 0.64 & 7.18 & $\begin{array}{c}1.90 \\
(1.19-3.06)\end{array}$ & 0.007 \\
$\begin{array}{l}\text { Presence of } \\
\text { depression }\end{array}$ & 2.87 & 59.39 & $\begin{array}{c}17.76 \\
(8.54-36.92)\end{array}$ & $<0.001^{*}$ \\
$\begin{array}{l}\text { Presence of trait } \\
\text { anxiety }\end{array}$ & 0.22 & 9.43 & 1.25 & 0.002 \\
\hline${ }^{*}$ Highlysignificant. & & & &
\end{tabular}

depression (61\% vs. $48 \%)$ and more severe and very severe trait anxiety (30\% vs. $20 \%$ ) than male students did, and severity of depression and anxiety were correlated with smartphone addiction. Generally, the cause of that gender difference is still not well understood. It could be explained by the significantly higher prevalence of depression among female participants and the known vicious circle between smartphone addiction and depression (27). Some studies have attributed this difference to the extensive female use of smartphones for social purposes compared to men $(21,27,28)$. For more understanding of that gender difference, further research is needed to assess genderrelated predictors of smartphone addiction.

In the present study there were significant positive correlations between smartphone addiction and both depression and trait anxiety scores, which has been found in international studies $(5,6,9,10)$ and Saudi studies (15), including 1 in Taif university (5). According to the conclusions from previous studies, smartphone addiction forms a vicious cycle with psychopathology (29). The overuse of mobile phones may increase stress by the continuous checking and response to text messages and notifications (29). This excessive reassurance-seeking behaviour is associated with depression and anxiety (29). Smartphone overuse forces the user to be awake late at night, leading to sleep problems and worsening depression and stress (4). Electromagnetic waves from mobile phones also delay melatonin production and lead to sleep disorders and depression (30). Other studies found that depression is a predictor for mobile phone addiction, as depressed individuals overuse smartphones as a coping mechanism to rid themselves of stress and depressive emotions (31).

In the present study, the 6th year students had significantly higher PUMP scores than students from other years, which is in agreement with another Saudi study (14). However, this is in contrast with other studies that have shown the inverse relationship between age and addictive use of technologies (21). This disagreement could be explained by the older age of our sample of university students who use smartphones for both educational and entertainment purposes, which 
make them vulnerable to addiction (7-10).

The present study showed that single, compared to married, students had significantly higher PUMP scores. This is in line with other studies in which being single was associated with addictive social networking $(13,21)$. There was a nonsignificant difference between PUMP scores and family monthly income in the present study. This differed from a Malaysian study in which students with higher income had significantly more mobile phone use (32). This variation could be attributed to the different sociocultural factors and socioeconomic standard of Saudi Arabia, which has an oil-based economy (33). This could explain the high and growing rate of smartphone use in Saudi Arabia, which was estimated to be $63.17 \%$ in 2016 (34).

Students from the theoretical college showed significantly higher levels of PUMP scores compared to health college students. This could be attributed to the large number of time-consuming tasks of health colleges students who have condensed academic courses, continuous assessments and examinations (22), giving them insufficient time to use smartphones, compared to the theoretical college students. In addition, Saudi medical students are engaged in practical training courses in hospitals as well as studying for the Saudi Medical Licensure Examination (35).

We found significantly higher PUMP scores among students who had an average duration of daily mobile use of $>4$ hours, which is consistent with previous studies (7,8,13-15). The significant positive correlation found between PUMP scores and the average duration of each daily call has also been reported in previous studies $(7,8)$.

The younger age of owning a smartphone was significantly associated with smartphone addiction (9). Similarly, we found a significant positive correlation between PUMP scores and duration of owning a smartphone.

In the present study, the risk factors for smartphone addiction were being female or single, older age, or having depression or trait anxiety. This agrees with the results of a wide range of studies done to address this issue $(5,6,9,10,13,14,21,27,28)$. This reinforces the reported gender difference regarding smartphone addiction.

One of the limitations of this study was using a self-reported questionnaire that had the possibility of reporting bias. Another limitation was being a crosssectional study that showed the relation between variables but impeded the detection of the cause-effect relationship. The present study was a single centre study that precludes generalization of the results.

\section{Conclusion}

The present study showed that smartphone addiction is a major problem among Saudi university students, and is associated with psychological disorders such as depression and trait anxiety. The study calls for future research on larger numbers of students from other universities to allow the generalization of results. Gender-related predictors of smartphone addiction should be investigated in those studies to explore motivations and contents of smartphone use that lead to that behavioural problem. We recommend raising the awareness of university students about the negative effects of smartphones through health education campaigns, in addition to carrying out counselling campaigns with the help of expert psychotherapists to help smartphone addicts to overcome this problem. These interventions should take in consideration the observed gender difference of the problem.

\section{Acknowledgements}

The authors gratefully acknowledge the support provided by the officials of the studied colleges for facilitating the administrative aspects of the research. Special thanks to participant students for their cooperation.

Funding: None.

Competing interests: None declared.

\section{Schéma d'utilisation du téléphone portable et dépendance rapportés à la dépression et l'anxiété \\ Résumé}

Contexte : Les étudiants universitaires qui utilisent leur smartphone de manière intensive s'exposent à une dépendance vis-à-vis du téléphone portable potentiellement liée à la dépression et à l'anxiété réactionnelle.

Objectifs : Évaluer les différences entre les sexes en termes de modes d'utilisation du smartphone et de dépendance rapportés à la dépression et l'anxiété réactionnelle parmi les étudiants universitaires en Arabie saoudite.

Méthodes : Une étude transversale a été menée auprès de 1513 étudiants de l’Université de Taif (Arabie saoudite). Un questionnaire auto-administré a été utilisé pour recueillir des données démographiques ainsi que des données sur les schémas d'utilisation du smartphone. L'échelle PUMP (Problematic Use of Mobile Phones, ou usage problématique du téléphone portable) a été utilisée pour établir la dépendance vis-à-vis du smartphone. La version arabe validée de l'échelle 
d'anxiété manifeste de Taylor et de l'inventaire de dépression de Beck a été utilisée pour évaluer respectivement l'anxiété réactionnelle et la dépression.

Résultats : Une prédominance féminine a été relevée concernant la prévalence de la dépression et de l'anxiété réactionnelle, les scores PUMP, la durée d'utilisation quotidienne du téléphone portable et le nombre quotidien d'appels. Une corrélation positive importante a été établie entre le score PUMP et les scores d'évaluation de la dépression et de l'anxiété réactionnelle, l'ancienneté de possession du smartphone et la durée moyenne de chaque appel quotidien. Les scores PUMP étaient comparativement beaucoup plus élevés chez les étudiants de sixième année, ceux suivant des études théoriques, les étudiants célibataires et les étudiants qui utilisent un smartphone plus de quatre heures par jour.

Conclusions : La dépendance vis-à-vis du smartphone est un problème majeur chez les étudiants universitaires en Arabie saoudite. Elle est associée à la dépression et à l'anxiété réactionnelle. Les études futures devraient viser à établir les meilleures interventions pour protéger les étudiants universitaires des effets négatifs des smartphones.

$$
\begin{aligned}
& \text { نمط وإدمان استخدام الهاتف النقال وعلاقة ذلك بالاكتئاب و القلق } \\
& \text { داليا السيد دسوقي، هاني أبو زيد }
\end{aligned}
$$

الخلفية: يتعرض طلاب الجامعة من يستخدمون الهو اتف الذكية بنهم شديد لخطر الإدمان الذي قد يرتبط بالاكئاب و القلق الشخصي.

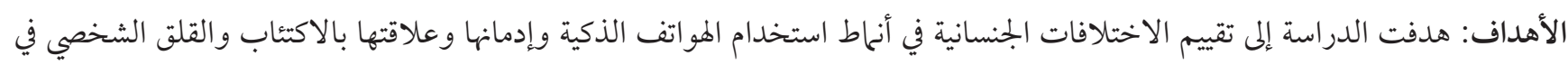
صفوف طلاب الجامعات السعودية.

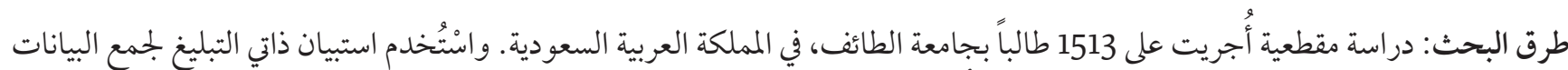

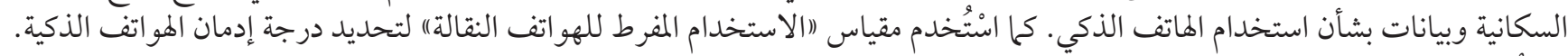

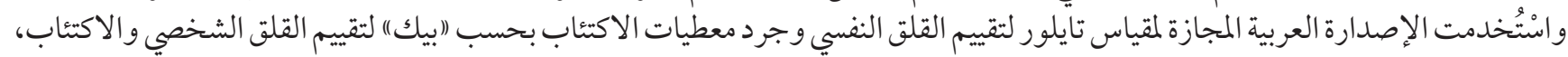
على التو الي.

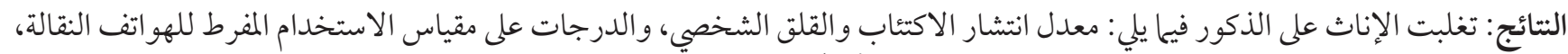

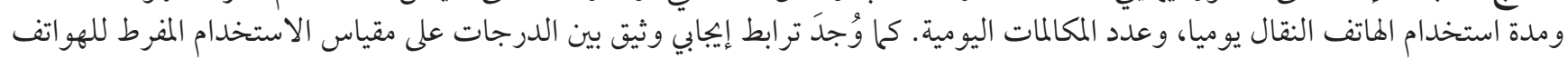

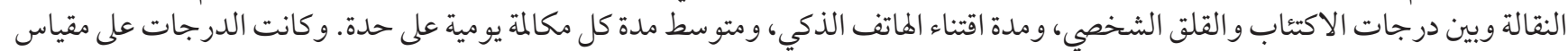

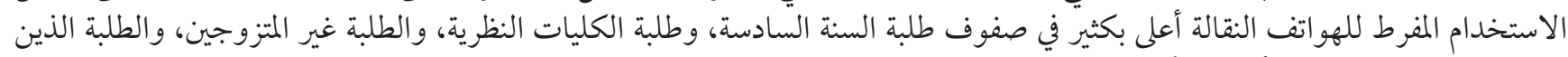

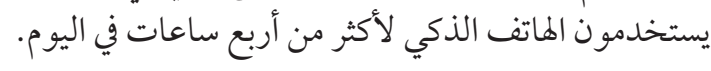

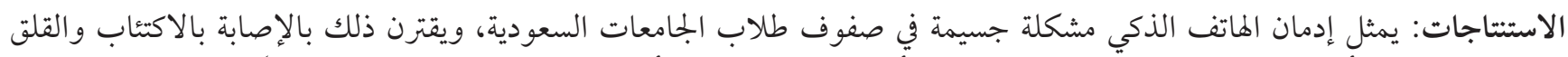

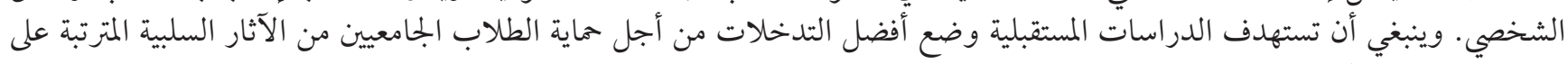
استخدام الهو اتف الذكية.

\section{References}

1. Chen B, Liu F, Ding S, Ying X, Wang L, Wen Y. Gender differences in factors associated with smartphone addiction: a cross-sectional study among medical college students. BMC Psychiatry 2017 Oct 10;17(1):341-50. http://dx.doi.org/10.1186/s12888-017-1503-z PMID:29017482

2. Clayton RB, Leshner G, Almond A. The extended iSelf: the impact of iPhone separation on cognition, emotion, and physiology. J Computer-Mediated Commun. 2015;20(2):119-35. https://doi.org/10.1111/jcc4.12109

3. Choi S, Mok J, Kim D, Choi J, Lee J, Ahn H, Choi E, Song W. Latent class analysis on internet and smartphone addiction in college students. Neuropsychiatry Dis Treat. 2014 May 20;10:817-28. http://dx.doi.org/10.2147/NDT.S59293 PMID:24899806

4. Zarghami M, Khalilian A, Setareh J, Salehpour G. The impact of using cell phones after light-out on sleep quality, headache, tiredness, and distractibility among students of a university in North of Iran. Iran J Psychiatry Behav Sci. 2015 Dec;9(4):e2010. http://dx.doi.org/10.17795/ijpbs-2010 PMID:26834802

5. Elhai JD, Dvorak RD, Levine JC, Hall BJ. Problematic smartphone use: A conceptual overview and systematic review of relations with anxiety and depression psychopathology. 2017 Jan 1;207:251-9. http://dx.doi.org/10.1016/j.jad.2016.08.030 PMID:27736736

6. Hong FY, Chiu SI, Huang DH. A model of the relationship between psychological characteristics, mobile phone addiction and use of mobile phones by Taiwanese university female students. Comput Hum Behav. 2012 Nov;28(6):2152-9. https://doi. org/10.1016/j.chb.2012.06.020

7. Kimb SM, Huh HJ, Cho H, Kwon M, Choi JH, Ahn HJ, PhD, Sun Woo Lee SW, Kim YJ, Kim DJ. The effect of depression, impulsivity, and resilience on Smartphone Addiction in University Students. J Korean Neuropsychiatr Assoc. 2014 Jul;53(4):214-20. http:// 
dx.doi.org/10.4306/jknpa.2014.53.4.214

8. Lee H, Ahn H, Choi S, Choi W. The SAMS: Smartphone Addiction Management System and verification. J Med Syst. 2014 Jan;38(1):1-10. http://dx.doi.org/10.1007/s10916-013-0001-1 PMID:24395031

9. Boumosleh MJ, Jaalouk D. Depression, anxiety, and smartphone addiction in university students - a cross sectional study. PLoS One. 2017 Aug 4;12(8):e0182239. http://dx.doi.org/10.1371/journal.pone.0182239 PMID:28777828

10. Hegazy AA, Alkhail BA, Awadalla NJ, Qadi M, Al-Ahmadi J. Mobile phone use and risk of adverse health impacts among medical students in Jeddah, Saudi Arabia. Br J Med Med Res. 2016,15(1):1-11. http://dx.doi.org/10.9734/BJMMR/2016/24339

11. Kim D, Lee Y, Lee J, Nam JK, Chung Y. Development of Korean Smartphone Addiction Proneness Scale for Youth. PLoS One. 2014 May 21;9(5):e97920. http://dx.doi.org/10.1371/journal.pone.0097920

12. KSA leads the world in mobile usage. https://www.itp.net/588729-ksa-leads-the-world-in-mobile-usage, accessed 27 January 2020.

13. Aljomaa SS, Al-Qudah MF, Albursan IS, Bakhiet SF, Abduljabbar AS. Smartphone addiction among university students in the light of some variables. Comput Human Behav. 2016 Aug;61:155-64. https://doi.org/10.1016/j.chb.2016.03.041

14. Alosaimi FD, Alyahya H, Alshahwan H, Al Mahyijari N, Shaik SA. Smartphone addiction among university students in Riyadh. Saudi Arabia. Saudi Med J. 2016 Jun;37(6):675-83. http://dx.doi.org/10.15537/Smj.2016.6.14430 PMID:27279515

15. Al-Dossary NA, Al-Thebait AA, Al-Awwad AA, Al-Anzi RZ, Asseri TM. The association between smartphone use pattern, smartphone addiction, and depression among female secondary school students in Khobar, Saudi Arabia. Int J Sci Res. 2017;6(8):310-4. http://dx.doi.org/10.36106/ijsr

16. Pawłowska B, Potembska E. Gender and severity of symptoms of mobile phone addiction in Polish gymnasium, secondary school and university students. Curr Probl Psychiatry. 2012;12(4):433-8.

17. Merlo LJ, Stone AM, Bibbey A. Measuring problematic mobile phone use: development and preliminary psychometric properties of the PUMP scale. J Addict. 2013:912807. https://doi.org/10.1155/2013/912807

18. Bianchi A, Phillips JG. Psychological predictors of problem mobile phone use. CyberPsychol Behav. 2005 Feb 28;8(1):39-51. http:// doi.org/10.1089/cpb.2005.8.39

19. Fahmi M, Ghali M, Meleka K. Arabic version of the personality scale of manifest anxiety. Egyptian Psychiatry. 1977,11:119-26.

20. Beck AT, Steer RA, Carbin MG. Psychometric properties of the Beck Depression Inventory: twenty-five years of evaluation Clin Psychol Rev. 1988;8:77-100.

21. Andreassen CS, Billieux J, Griffiths MD, Kuss DJ, Demetrovics Z, Mazzoni E, Pallesen S. The relationship between addictive use of social media and video games and symptoms of psychiatric disorders: a large-scale cross-sectional study. Psychol Addict Behav, 2016 Mar;30(2):252-62. http://dx.doi.org/10.1037/adboooo160 PMID:26999354

22. Alzahrani AH. Depression and suicide among medical students: a comparison study between medical and medical sciences students in Taif University, Taif-KSA. Int J Med Sci Public Health 2017;6(5):964-8. http://dx.doi.org/10.5455/ijmsph.2017.0954227012017

23. Alshehri A, Alzahrani H, Alotaibi M. Internet Addiction among Taif university students and its association with psychiatric co-morbidities. Merit Res J Med Med Sci. 2015 Dec;3(12):536-44. http://www.meritresearchjournals.org/mms/index.htm

24. Zaini R, Anjum F, Dahlawi H. Assessment of depression among applied medical science college students at Taif University: a questionnaire survey. J Psychiatry. 2017;21:1-3. http://dx.doi.org/10.4172/2378-5756.1000431

25. Iqbal W, Khan AM, Khan SA. Problematic mobile phone among medical students using PUMP Scale. JMHS. 2017 JulSep;11(3):1127-9. http://www.pjmhsonline.com/2017/july_sep/pdf/1127.pdf

26. Dhanasekaran RS, Arumugam B, Vaanan E. Problematic usage of mobile phones among adolescents in Chennai - a cross sectional study. Natl J Res Community Med. 2017;6(Suppl. 2):170-73. https://journals.indexcopernicus.com/api/file/viewByFileId/285960.pdf

27. van Deursen AJAM, Bolle CL, Hegner SM, Kommers PAM. Modeling habitual and addictive smartphone behavior: The role of smartphone usage types, emotional intelligence, social stress, self-regulation, age, and gender. Comput Human Behav, 2015 Apr;45:411-20. https://doi.org/10.1016/j.chb.2014.12.039

28. Kim Y, Jeong JE, Cho H, Jung DJ, Kwak M, Rho MJ, Yu H, Kim DJ, Choi IY. Personality Factors Predicting Smartphone Addiction Predisposition: Behavioral Inhibition and Activation Systems, Impulsivity, and Self-Control. PLoS One, 2016 Aug 17;11(8):e0159788. http://dx.doi.org/10.1371/journal.pone.0159788 PMID:27533112

29. Billieux J, Maurage P, Lopez-Fernandez O, Kuss DJ, Griffith s MD. Can disordered mobile phone use be considered a behavioral addiction? An update on current evidence and a comprehensive model for future research. Curr Addict Rep. 2015;2(2):156-162. http://dx.doi.org/10.1007/s40429-015-0054-y

30. Wood AW, Loughran SP, Stough C. Does evening exposure to mobile phone radiation affect subsequent melatonin production? Int J Radiat Biol. 2006 Feb;2(2):69-76. http://dx.doi.org/10.1080/09553000600599775 PMID:16546905

31. Kim R, Lee KJ, Choi YJ. Mobile phone overuse among elementary school students in Korea: factors associated with mobile phone use as a behavior addiction. J Addict Nurs. 2015 Apr-Jun;26(2):81-5. http://dx.doi.org/10.1097/JAN.0000000000000074 PMID:26053080 
32. Zulkefly S, Baharudin R. Mobile phone use amongst students in a university in Malaysia: its correlates and relationship to psychological health. Eur J Sci Res. 2009;37(2):206e218. http://psasir.upm.edu.my/id/eprint/7060/1/mobile_phone.pdf

33. A. Alkhathlan K. Contribution of oil in economic growth of Saudi Arabia. Appl Econ Lett. 2013;20(4):343-8. https://doi.org/10.1080 /13504851.2012.703310

34. The Statistics Portal: Technology \& Telecommunications. Smartphone penetration rate as share of the population in Saudi Arabia from 2015 to 2022. https://www.statista.com/statistics/625436/smartphone-user-penetration-in-saudi-arabia/

35. Galinović I, Vuković V, Troselj M, Antić S, Demarin V. Migraine and tension type headache in medical students: a questionnaire study. Collegium Antropologicum 2009;33(1):169-73. 